\title{
Penggunaan Teknik Obat dan Permasalahan Blokade Epidural di Wilayah Jawa Barat pada Tahun 2015
}

\author{
Muhammad Ibnu, Dedi Fitri Yadi, Ezra Oktaliansah \\ Departemen Anestesiologi dan Terapi Intensif \\ Fakultas Kedokteran Universitas Padjadjaran/RSUP Dr. Hasan Sadikin Bandung
}

\begin{abstract}
Abstrak
Blokade epidural merupakan salah satu jenis anestesi regional yang memiliki rentang implikasi lebih luas dibanding dengan blokade spinal. Perbedaan teknik maupun rejimen obat untuk blokade epidural meningkat seiring dengan meningkatnya ketertarikan di bidang anestesi regional dikarenakan teknik anestesi regional memberikan efek analgesi yang efektif tanpa memengaruhi kesadaran pasien dan meningkatkan kenyamanan pasien. Tujuan penelitian ini mencari data mengenai penggunaan, teknik, rejimen obat, dan permasalahan yang dialami oleh dokter anestesi di Jawa Barat dalam melakukan blokade epidural. Penelitian ini dilakukan pada bulan Agustus hingga September 2016 di Departemen Anestesiologi dan Terapi Intensif RSUP Dr. Hasan Sadikin Bandung. Penelitian ini bersifat deskriptif dengan pengambilan data menggunakan kuesioner dan pendekatan cross sectional. Kuesioner dikirimkan kepada 120 dokter spesialis anestesi di Jawa Barat melalui jasa pos dan 30 kuesioner diberikan langsung kepada dokter spesialis anestesi yang bekerja di RSUP Dr. Hasan Sadikin Bandung. Angka respons yang didapatkan sebesar 47,3\%. Hasil penelitian ini didapatkan dokter spesialis anestesi yang masih melakukan blokade epidural pada tahun 2015 sebesar 73,2\%, teknik penusukan yang paling banyak dilakukan adalah pendekatan midline sebesar 73\%, dan identifikasi rongga epidural paling banyak dengan pendekatan lost of resistance sebesar $80,7 \%$. Obat anestesi lokal yang paling banyak digunakan untuk blokade epidural adalah bupivakain sebesar $95,9 \%$. Adjuvan yang paling banyak digunakan adalah fentanil sebesar $92,3 \%$. Permasalahan yang berkaitan dalam pelaksanaan tindakan blokade epidural pada tahun 2015 paling banyak adalah permasalahan staf di ruangan dalam membantu menangani pasien dengan epidural, yaitu sebesar 38,03\%.
\end{abstract}

Kata kunci: Blokade epidural, rejimen obat, teknik

\section{Epidural Blockade Administration Technique and Issues in West Java in 2015}

\begin{abstract}
Epidural blockade is one of the regional anesthesia techniques with wider implication than the spinal blockade. The techniques and drug regimens used in epidural blockade vary with the increasing interest on regional anesthesia due to its effective analgesic effect without decreasing consciousness and by increasing patients' comfort. The purpose of this study was to explore the use, techniques, drug regimens, issues experienced by anesthesiologists in West Java in performing epidural blockade. This study was conducted from August to September 2016 at the Department of Anesthesiology and Intensive Therapy, Dr. Hasan Sadikin Hospital Bandung. This was a cross-sectional descriptive study using a questionnaire. Questionnaires were mailed to 120 anesthesiologists in West Java area and 30 additional questionnaires were distributed directly to anesthesiologists working at Dr. Hasan Sadikin General Hospital Bandung. The response was $47.3 \%$. This study showed that $73.2 \%$ anesthesiologists performed epidural blockade in 2015 , with $73 \%$ used the midline approach and $80.7 \%$ used the loss of resistance method to identify the epidural space. The majority used bupivacaine (95.5\%) as the local anesthetics. The most frequently used adjuvant was fentanyl (95.9\%). The most frequently mentioned problem associated with epidural blockade in 2015 was the lack of staff's ability to assist the anesthesiologist in performing epidural blockade (38.03\%).
\end{abstract}

Key words: Drug regimens, epidural blockade, technique

Korespondensi: Muhammad Ibnu, dr., SpAn, RSUD Pemangkat, Jalan Abdul Kadir Kasim, No. 20. Kecamatan Pemangkat Kabupaten Sambas, Kalimantan Barat, Email ibunqumaira@gmail.com 


\section{Pendahuluan}

Anestesi regional merupakan teknik yang dapat digunakan sebagai alternatif anestesi umum maupun sebagai kombinasi dengan anestesi umum, pada saat ini sudah menjadi prosedur yang populer dan merupakan bagian yang penting dalam praktik anestesi. Teknik ini menghasilkan blokade yang lebih spesifik, efek adekuat dalam menghilangkan nyeri, memiliki pengaruh yang baik terhadap operasi pada tulang serta jaringan sekitarnya yang pada kasus-kasus tertentu anestesi umum harus dihindari karena risiko yang tinggi terhadap hasil luaran, selain itu penggunaan opioid sistemik juga dapat dikurangi. ${ }^{1-3}$

Penelitian terbaru menunjukkan bahwa teknik anestesi regional juga memiliki efek positif terhadap hasil luaran pasien seperti mengurangi respons inflamasi, memperbaiki fungsi usus, faktor koagulasi, dan menurunkan angka rekurensi suatu keganasan. Anestesi epidural merupakan salah satu dari jenis blok neuroaksial yang dapat dilakukan oleh seorang dokter anestesi. Penggunaan teknik blokade epidural dapat dilakukan di lumbal maupun torakal yang dapat berperan sebagai anestesi maupun analgesi, serta dapat dipergunakan secara tunggal maupun kombinasi dengan anestesi spinal atau anestesi umum. . $^{13,4}$

Beberapastudimengenaipenggunaanteknik anestesi regional telah dilakukan, berdasar atas penelitian di Yunani dilakukan survei terhadap 128 departemen anestesi selama bulan Maret hingga Juni 2012 menggunakan kuesioner didapatkan 66 (51,6\%) departemen anestesi yang telah memberikan respons. Penelitian ini menyatakan bahwa penggunaan anestesi regional sebanyak $45,5 \%$ dari total keseluruhan operasi, penggunaan anestesi regional spinal paling banyak dilakukan sekitar 51,9\%, epidural 23,2\%, kombinasi spinal epidural 11,24\%, dan blok saraf perifer sebanyak $13 \%{ }^{1}$

Survei di Nigeria yang disebarkan kepada 196 dokter anestesi, terdapat 140 dokter yang telah memberikan jawaban dengan angka respons 71,4\%. Sekitar 92,9\% dokter anestesi di Nigeria melakukan anestesi spinal, hanya
$15 \%$ yang menggunakan anestesi epidural, 2,9\% menggunakan blok saraf perifer, dan didapatkan 25,7\% tidak pernah melakukan epidural. $^{2}$

Jawa Barat merupakan salah satu dari 35 provinsi yang ada di Indonesia. Provinsi ini terdiri atas 9 kota dan 18 kabupaten dengan jumlah dokter anestesi sebanyak 150 orang. Sampai saat ini belum pernah dilakukan penelitian mengenai penggunaan, teknik, dan rejimen obat yang digunakan pada blokade epidural. Oleh karena itu, peneliti tertarik melakukan penelitian ini dengan tujuan mengetahui data mengenai penggunaan blokade epidural, teknik dan rejimen obatyang digunakan, dan kemungkinan permasalahan dalam melakukan blokade epidural oleh dokter anestesi di Jawa Barat pada tahun 2015.

\section{Subjek dan Metode}

Penelitian ini dilakukan setelah mendapat persetujuan dari Komite Etik Penelitian Kesehatan Fakultas Kedokteran Universitas Padjadjaran/RSUP Dr. Hasan Sadikin Bandung. Penelitian ini dilakukan dengan menyebarkan kuesioner kepada seluruh dokter spesialis anestesi yang menyelesaikan masa studi sebelum tahun 2015 dan masih aktif pelayanan di wilayah PERDATIN Jawa Barat pada bulan Agustus hingga September 2016. Sampel yang dipergunakan merupakan nonprobabilitas dengan teknik purposive sampling.

Penelitian ini merupakan penelitian yang bersifat deskriptif prospektif dengan teknik pengambilan data melalui kuesioner dan pendekatan cross sectional. Data anggota Perhimpunan Dokter Anestesi dan Terapi Intensif Indonesia (PERDATIN) Jawa Barat didapatkan dari sekretariat PERDATIN Jawa Barat yang kemudian dilakukan crosscheck terlebih dahulu dengan cara menghubungi salah satu anggota PERDATIN di wilayah kerja masing-masing. Data diambil menggunakan amplop yang berisi kuesioner yang disebarkan menggunakan jasa pos. Analisis pengolahan data terhadap kuesioner yang telah diberikan dilakukan mempergunakan perangkat lunak Microsoft Excell. 


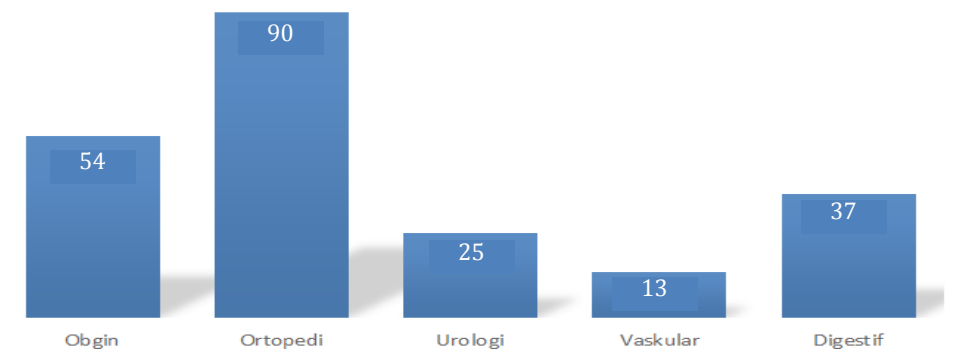

Gambar 1 Jenis Operasi pada Penggunaan Blokade Epidural

\section{Hasil}

Jumlah peserta penelitian ini terdiri atas 150 dokter spesialis anestesi, didapatkan 71 dokter yang memberikan jawaban, 55 di antaranya melalui jasa pos dan 16 lainnya memberikan jawaban kuesioner langsung kepada peneliti. Dari hasil tersebut didapatkan angka respons sebesar 47,3\%. Dokter spesialis anestesi di Jawa Barat yang masih melakukan blokade epidural selama tahun 2015 sebanyak 52 dokter atau sebesar 73\%, dan didapatkan sebanyak 19 dokter spesialis anestesi atau sebesar $27 \%$ tidak melakukan blokade epidural.

\section{Tabel 1 Teknik Blokade epidural}

\begin{tabular}{lc}
\hline \multicolumn{1}{c}{ Variabel } & n= 52 \\
\hline Posisi & \\
Duduk & $16(31 \%)$ \\
Lateral & $8(15 \%)$ \\
Keduanya & $28(54 \%)$ \\
Penusukan & \\
Midline & \\
Paramedian & $38(73 \%)$ \\
Keduanya & $0(0 \%)$ \\
Identifikasi & $14(27 \%)$ \\
Lost of resistance & \\
Hanging drop & $42(81 \%)$ \\
Keduanya & $1(2 \%)$ \\
Test dose & $9(17 \%)$ \\
Menggunakan & \\
Tidak menggunakan & $41(79 \%)$ \\
Tidak selalu & $3(6 \%)$ \\
\hline
\end{tabular}

Dokter spesialis anestesi di wilayah Jawa Barat yang melakukan blokade epidural untuk operasi obstetri dan ginekologi pada tahun 2015 sebesar 54\%, untuk operasi ortopedi sebesar 90\%, untuk operasi urologi sebesar $25 \%$, untuk operasi vaskular sebesar $13 \%$, dan untuk operasi digestif 37\%. (Gambar 1).

Dokter spesialis anestesi paling banyak melakukan blokade epidural dengan frekuensi 1 kali per bulan 37\%, sedangkan yang melakukan dengan frekuensi lebih dari atau sama dengan 4 kali per bulan hanya $8 \%$ (Gambar 2).

Teknik blokade epidural yang diidentifikasi meliputi posisi pasien pada saat melakukan blokade epidural, cara penusukan, cara identifikasi rongga epidural, dan penggunaan test dose. Dokter spesialis anestesi paling banyak memposisikan pasien dengan duduk maupun lateral pada saat penusukan, yaitu

\section{Tabel 2 Rejimen Obat untuk Blokade} Epidural

\begin{tabular}{lc}
\hline \multicolumn{1}{c}{ Variabel } & n=52 \\
\hline Anestesi lokal & \\
Bupivakain & $35(67 \%)$ \\
Lidokain & $1(2 \%)$ \\
Ropivakain & $1(2 \%)$ \\
Bupivakain, ropivakain & $4(8 \%)$ \\
Bupivakain, lidokain & $7(13 \%)$ \\
Bupivakain, ropivakain, lidokain & $4(8 \%)$ \\
Adjuvan & \\
Fentanil & $40(77 \%)$ \\
Klonidin & $1(2 \%)$ \\
Fentanil, klonidin & $1(2 \%)$ \\
Fentanil, morfin & $7(13 \%)$ \\
Tanpa adjuvant & $3(6 \%)$ \\
\hline
\end{tabular}




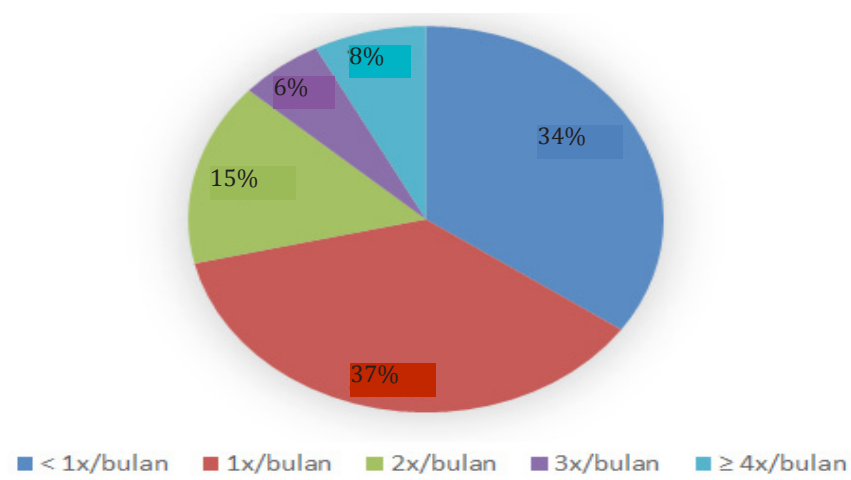

Gambar 2 Frekuensi Penggunaan Blokade Epidural pada Tahun 2015

sebesar 54\%. Penusukan paling banyak menggunakan midline, yaitu sebesar $73 \%$. Identifikasi paling banyak dengan cara lost of resistance sebesar $81 \%$. Didapatkan $6 \%$ dokter anestesi tidak melakukan test dose (Tabel 1).

Dari hasil penelitian didapatkan sebanyak 50 dokter spesialis anestesi (96\%) di wilayah Jawa barat menggunakan bupivakain sebagai obat anestesi lokal untuk blokade epidural, dari 50 dokter tersebut sebanyak 15 dokter menggunakan obat anestesi lokal lain (ropivakain atau lidokain), 35 dokter hanya menggunakan bupivakain, sedangkan 1 dokter spesialis anestesi hanya menggunakan ropivakain dan 1 dokter hanya menggunakan lidokain sebagai obat anestesi lokal pada blokade epidural (Tabel 2).

Permasalahan yang berkaitan dalam melakukan tindakan blokade epidural yang paling banyak adalah permasalahan kemampuan staf di ruangan dalam membantu menangani pasien yang mendapatkan epidural untuk penanganan nyeri pascaoperasi, yaitu sebesar 38\%, masalah selanjutnya adalah keterbatasan alat untuk blokade epidural sebesar 37\%, dan diikuti dengan masalah implementasi teknik dalam melakukan blokade epidural dengan persentase sebesar 27\%. (Gambar 3).

\section{Pembahasan}

Blokade epidural merupakan salah satu dari jenis neuroaksial yang dapat digunakan pada saat operasi, pascaoperasi, maupun untuk penanganan nyeri. Blokade ini dapat digunakan secara tunggal maupun kombinasi dengan anestesi umum atau sedasi. Anestesi epidural adalah salah satu teknik anestesi regional yang menempatkan obat anestesi lokal di dalam ruang epidural. Banyak keuntungan yang diperoleh dari teknik anestesi regional di antaranya relatif lebih murah, pengaruh sistemik lebih kecil, menghasilkan analgesi adekuat, mampu mencegah respons stres lebih sempurna, mengurangi perdarahan selama

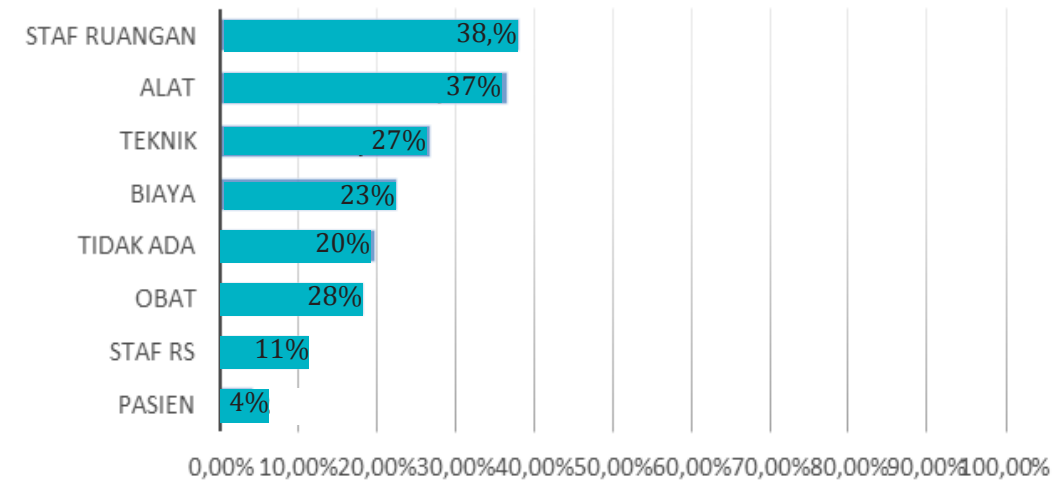

Gambar 3 Permasalahan pada Penggunaan Blokade Epidural 
pembedahan, mengurangi lama perawatan di rumah sakit, di samping itu juga memiliki efek anti-inflamasi dan antikanker. Saat ini sudah banyak digunakan blokade kontinu (epidural maupun saraf tepi) untuk penanganan nyeri pascaoperasi. $^{5-7}$

Data yang didapat dari sekertariat PERDATIN Jawa Barat, dokter spesialis anestesi di wilayah PERDATIN Jawa Barat yang menyelesaikan masa studi sebelum tahun 2015 dan masih aktif melakukan pelayanan berjumlah 150 dokter. Peneliti melakukan crosscheck alamat dan juga pemberitahuan mengenai penelitian melalui telepon sebelum melakukan penyebaran kuesioner. Peneliti melampirkan surat rekomendasi dari ketua PERDATIN Jawa Barat pada kuesioner yang disebar. Didapatkan 71 dokter spesialis anestesi yang memberikan jawaban dari kuesioner dengan angka respons sebesar 47,3\%. Hasil ini serupa dengan penelitian mengenai sistem pelatihan teknik epidural pada peserta pelatihan obstetric anesthesia ascociation (OAA) yang dilakukan di Inggris pada tahun 2012, dari 453 peserta didapatkan angka respons sebesar $46 \%$.

Tahun 2009 di Amerika dilakukan penelitian mengenai praktik anestesi pada operasi sectio caesarean. Penelitian dilakukan dengan metode survei, kuesioner disebar melalui email kepada 1.081 dokter anestesi dan didapatkan angka respons sebesar 36\%.

Penelitian lainnya dilakukan di Cina pada bulan Desember 2015 sampai dengan Januari 2016 mengenai praktik anestesi regional. Survei dikirim melalui salah satu media sosial, dari total 6.589 dokter anestesi didapatkan 2.654 dokter yang memberikan jawaban, dengan angka respons 40\%. ${ }^{8}$ Tahun 2012 di Arab Saudi dilakukan survei mengenai gambaran penggunaan anestesi regional dan kebutuhan terhadap pelatihan di bidang anestesi regional, kuesioner disebarkan pada 382 dokter anetesi dan didapatkan angka respons $55,2 \%{ }^{5}$

Tahun 2012 di Yunani dilakukan survei mengenai gambaran penggunaan anestesi regional, kuesioner dikirim melalui email kepada 128 departemen anestesi dan didapatkan angka respons sebesar 51,56\%. ${ }^{1}$ Angka respons adalah jumlah dokter anestesi di wilayah Jawa Barat yang memberikan respons dengan memberikan jawaban kuesioner. Angka respons yang rendah di Jawa Barat kemungkinan disebabkan oleh beberapa jawaban kuesioner kembali melewati batas waktu yang ditentukan. Selain itu, banyak didapatkan responden yang tidak mengembalikan kuesioner walaupun sudah dikonfirmasi melalui telepon, hal ini menunjukkan umpan balik yang rendah dari dokter anestesi di wilayah Jawa Barat.

Jumlah dokter spesialis anestesi di wilayah PERDATIN Jawa Barat yang masih melakukan blokade epidural pada tahun 2015 sebanyak 52 dokter atau sebesar 73\%, sedangkan dokter spesialis anestesi yang tidak melakukan blokade epidural pada tahun 2015 sebanyak 19 dokter atau sebesar 27\%. Beberapa penelitian di negara lain, seperti di Etiopia, penggunaan blokade epidural pada tahun 2014 sebesar 4,76\%. Sekitar 5 dari 105 dokter spesialis anestesi yang masih melakukan blokade epidural. ${ }^{9}$ Survei di Nigeria, dokter spesialis anestesi yang melakukan blokade epidural sebesar $15 \%{ }^{2}$

Angka penggunaan blokade epidural untuk analgesia pada persalinan maupun untuk anestesi pada seksio cesarean di Israel pada tahun 2007 masing-masing sebesar 50\% dan $15 \%$. Penggunaan blokade epidural untuk operasi seksio cesarean di Republik Czech pada tahun 2011 sebesar 17\%, sedangkan untuk analgesi epidural pascaoperasi digunakan sebanyak $14 \% .^{10,11}$

Dokter spesialis anestesi di wilayah Jawa Barat yang melakukan blokade epidural dengan frekuensi nol sampai satu kali per bulan sebanyak 18 (35\%) dokter, satu kali per bulan sebanyak 19 (36\%) dokter, dua kali per bulan sebanyak $8(15 \%)$ dokter, tiga kali per bulan sebanyak 3 (6\%) dokter, lebih dari atau sama dengan empat kali per bulan sebanyak 4 dokter $(8 \%)$. Hal ini berbeda dengan negara lain, dokter anestesi militer di Inggris yang melakukan blokade epidural lebih dari satu kali per minggu sebesar $26,3 \%$, satu kali per minggu sebesar $17,5 \%$, satu kali per bulan 
sebesar $12,3 \%$, kurang dari satu kali per bulan sebesar $24,5 \%$, dan yang tidak melakukan blokade epidural sebesar 3,5\%. ${ }^{14}$

Dokter spesialis anestesi di Arab Saudi yang melakukan anestesi regional setiap hari sebesar $88,2 \%$, satu kali per minggu sebesar $31,8 \%$, dan satu kali atau lebih per bulan $17,1 \% .{ }^{5}$ Dapat disimpulkan bahwa frekuensi penggunaan blokade epidural di Jawa Barat masih rendah. Di Yunani angka penggunaan blokade epidural rendah disebabkan oleh dokter spesialis anestesi lebih memilih melakukan blokade spinal dengan alasan teknik pelaksanaan lebih mudah, memiliki onset yang cepat, kebutuhan obat yang lebih sedikit, dan ukuran jarum yang lebih kecil sehingga trauma yang dihasilkan lebih minimal.

Walaupun demikian, blokade epidural memiliki kelebihan bila dibanding dengan blokade spinal antara lain, dapat dilakukan blokade yang segmental, penurunan tekanan darah yang bertahap, dan dapat dilakukan pemasangan kateter untuk pemberian obat analgesi pascaoperasi. ${ }^{1}$ Maka dari itu, pada penelitian ini diharapkan dapat memberikan data mengenai permasalahan dokter spesialis anestesi di Jawa Barat dalam melakukan blokade epidural sehingga didapatkan solusi permasalahan tersebut.

Dari 52 dokter spesialis anestesi di wilayah PERDATIN Jawa Barat yang melakukan blokade epidural pada tahun 2015, didapatkan blokade epidural dilakukan pada 90\% kasus ortopedi, $54 \%$ pada operasi obstetri dan ginekologi, $37 \%$, pada operasi digestif, sebesar $25 \%$ pada operasi urologi, dan untuk vaskular sebesar $13 \%$.

Hal ini serupa dengan di Italia, dokter spesialis anestesi yang melakukan blokade epidural pada operasi ortopedi sebesar $70 \%$, urologi 50\%, dan bedah toraks kardiovaskular 50\%.7 Survei di Etiopia, dokter spesialis anestesi yang melakukan anestesi regional paling banyak pada operasi ortopedi sebesar $53,3 \%$ dan ginekologi 44,7\%. ${ }^{9}$ Hal ini berbeda dengan di Inggris dan Yunani, dokter spesialis anestesi di Inggris yang melakukan blokade epidural pada operasi digestif sebesar $40 \%$, obstetri 23\%, dan ortopedi hanya sebesar $17 \% \cdot{ }^{14}$ Dokter spesialis anestesi di Yunani yang melakukan blokade epidural untuk operasi obstetrik dan ginekologi sebesar 50,4\% dan ortopedi hanya $10,55 \%{ }^{1}$

Dokter spesialis anestesi di wilayah PERDATIN Jawa Barat yang menggunakan teknik lost of resistance untuk mengidentifikasi rongga epidural sebanyak 42 (81\%) dokter, sedangkan dokter yang menggunakan teknik hanging drop hanya 1 dokter. Dokter yang menggunakan teknik lost of resistance maupun hanging drop sebanyak 9 dokter atau sebesar $17 \%$. Hal ini serupa dengan di Cina bahwa pendekatan dengan cara lost of resistance menggunakan udara sebesar $48,87 \%$ dan menggunakan $\mathrm{NaCl}$ 0,9\% sebesar 44,32\%, sedangkan untuk pendekatan hanging drop hanya $6,82 \% .^{8}$ Survei di Inggris didapatkan dokter spesialis anestesi yang menggunakan teknik lost of resistance untuk mengidentifikasi rongga epidural sebesar $99 \% .{ }^{15}$ Penggunaan lost of resistance yang tinggi di Jawa Barat karena ada beberapa kelebihan teknik ini dibanding dengan teknik hanging drop. Pada teknik lost of resistance tekanan negatif dapat dirasakan langsung oleh dokter anestesi saat melakukan penusukan, risiko kerusakan duramater lebih kecil dibanding dengan teknik hanging drop, dan pada beberapa kasus dengan teknik hanging drop tidak didapatkan tekanan negatif pada saat melakukan identifikasi rongga epidural. ${ }^{16}$

Test dose adalah tindakan penyuntikan anestesi lokal dalam dosis kecil ke dalam rongga epidural yang kemudian dilakukan observasi terdapat tanda-tanda masuknya obat tersebut ke dalam rongga spinal maupun pembuluh darah. Tindakan ini harus dilakukan sebelum memberikan obat anestesi lokal pada blokade epidural. Pemberian lidokain $45 \mathrm{mg}$ dan epinefrin 15 mcg merupakan rejimen yang ideal untuk test dose. Tujuan pemberian test dose ini untuk menghindari masuknya obat anestesi lokal ke dalam rongga spinal maupun pembuluh darah dalam dosis yang besar. ${ }^{17}$

Penggunaan test dose di wilayah PERDATIN Jawa Barat selama tahun 2015 sebanyak 41 dokter spesialis anestesi atau sebesar 
$79 \%$ melakukan test dose terlebih dahulu, sedangkan 8 dokter atau sebesar 15\% tidak selalu menggunakan test dose, 3 dokter tidak pernah menggunakan test dose. Hal ini serupa dengan negara Italia bahwa dokter spesialis anestesi yang melakukan test dose sebanyak $93,18 \%$ dan hanya $6,82 \%$ dokter spesialis anestesi yang tidak melakukan test dose. ${ }^{7}$

Beberapa dokter anestesi di Jawa Barat berpendapat bahwa dengan melakukan identifikasi menggunakan teknik hanging drop maka sudah dapat dipastikan jarum berada di rongga epidural. Namun, hingga saat ini belum didapatkan literatur yang menganjurkan tindakan blokade epidural tanpa didahului test dose karena ujung kateter tetap harus dipastikan dengan cara melakukan test dose. Masuknya obat lokal anestesi ke dalam intravaskular pada saat melakukan teknik blokade epidural akan mengakibatkan komplikasi yang sangat serius. Banyak dokter anestesi menganggap bahwa epinefrin pada test dose merupakan teknik yang sensitif dan spesifik untuk mengidentifikasi kateter epidural pada intravaskular. ${ }^{17}$ Perlu dilakukan sosialisasi kepada dokter anestesi di Jawa Barat mengenai pentingnya melakukan test dose.

Penelitian saat ini didapatkan sebanyak 50 dokter spesialis anestesi (96\%) di wilayah PERDATIN Jawa Barat menggunakan bupivakain sebagai obat anestesi lokal untuk blokade epidural, dari 50 dokter tersebut sebanyak 15 dokter menggunakan obat anestesi lokal lain (ropivakain atau lidokain), 35 dokter hanya menggunakan bupivakain, 1 dokter spesialis anestesi hanya menggunakan ropivakain, dan 1 dokter hanya menggunakan lidokain sebagai obat anestesi lokal untuk rejimen pada blokade epidural. Hal ini serupa dengan beberapa negara lain, di antaranya di Jerman Penggunaan obat anestesi lokal yang paling banyak digunakan pada tahun 2005 , yaitu bupivakain $68,5 \%$ dan ropivakain $23,2 \%$. Obat anestesi lokal yang paling banyak digunakan di Cina, yaitu bupivakain sebanyak $70,65 \%$, kemudian ropivakain sebesar $28,07 \%$ dan lidokain sebesar $1,28 \%{ }^{8}$ Faktor yang memengaruhi pertimbangan pemilihan obat antara lain durasi operasi dan tujuan blokade (motorik atau hanya sensorik). ${ }^{9}$

Beberapa obat anestesi lokal, yaitu ropivakain dan levobupivakain dapat menjadi obat pilihan pada blokade neuroaksial maupun perifer karena toksisitas rendah meskipun diberikan dalam jumlah yang banyak. ${ }^{7}$ Bupivakain merupakan obat anestesi lokal yang sangat kardiotoksik, namun masih menjadi obat anestesi lokal yang paling banyak digunakan oleh dokter anestesi $\mathrm{i}^{12}$ termasuk di Jawa Barat. Hal ini dikarenakan harganya yang lebih murah dan mudah didapat dibanding dengan ropivakain maupun levobupivakain. ${ }^{12}$

Penggunaan adjuvan di wilayah PERDATIN Jawa Barat pada tahun 2015, sebanyak 48 (92\%) dokter spesialis anestesi menggunakan fentanil sebagai adjuvan dan terdapat 8 di antaranya menggunakan obat yang lain (7 menggunakan morfin dan 1 klonidin) sebagai adjuvan dan 40 dokter hanya menggunakan fentanil. Sekitar 10 (20\%) dokter spesialis anestesi tidak pernah menggunakan adjuvan sebagai rejimen obat pada anestesi blokade epidural. Hal ini serupa dengan beberapa negara lain antara lain berupa penggunaan adjuvan untuk epidural pada operasi seksio cesarean di Amerika paling banyak adalah fentanil, yaitu sebanyak 54\%, diikuti dengan morfin, bikarbonat, epinefrin, dan sufentanil berturut-turut sebesar 37\%, 42\%, 34\%, dan $2 \%$. Penggunaan obat yang paling banyak digunakan untuk analgesi epidural di Italia adalah levobupivakain dan ropivakain.

Penggunaan adjuvan epidural paling banyak dengan sufentanil, morfin, fentanil, klonidin, ketamin, dan epinefrin, yaitu sebesar $46,66 \%, 30 \%, 23,3 \%, 22,64 \%, 7,5 \%$, dan $5,3 \% .^{7}$ Penggunaan obat yang digunakan untuk analgesi epidural paling banyak di Inggris adalah bupivakain $0,1 \%$ dengan adjuvan fentanil $4 \mathrm{mcg} / \mathrm{mL}$, bupivakain $0,125 \%$ dengan adjuvan fentanil $2 \mathrm{mcg} /$ $\mathrm{mL}$, bupivakain $0,125 \%$ dengan adjuvan fentanil $4 \mathrm{mcg} / \mathrm{mL}$, yaitu sebanyak $28,5 \%$, $14,2 \%$, dan $10,7 \% .{ }^{15}$ Dokter spesialis anestesi yang menggunakan adjuvan untuk blokade epidural di Jerman sebesar $62 \%$, dari angka tersebut didapatkan $56,5 \%$ menggunakan 
sufentanil, 5\% menggunakan fentanil, dan $1,5 \%$ menggunakan morfin. ${ }^{3}$ Adjuvan yang paling banyak digunakan oleh dokter anestesi di Jawa Barat adalah fentanil.

Fentanil merupakan opioid yang bersifat hidrofobik dan memiliki kelarutan dalam lemak yang tinggi sehingga memiliki onset yang cepat, yaitu 10 menit pada pemberian epidural. Selain itu, juga fentanil tidak memiliki metabolit yang aktif. Suatu penelitian di negara lain yang dilakukan pada tahun 2008 memperlihatkan bahwa penambahan $2 \mathrm{mcg} / \mathrm{mL}$ fentanil dengan bupivakain 0,1\% pada blokade epidural meningkatkan potensi analgetik tanpa meningkatkan efek samping. ${ }^{19}$ Penggunaan morfin di Jawa Barat untuk adjuvan sedikit karena morfin merupakan obat golongan opioid yang memiliki sifat hidrofilik sehingga memiliki onset yang lambat, yaitu 30 menit pada pemberian epidural. Morfin memiliki durasi yang panjang, oleh sebab itu berpotensi terjadi absorpsi sistemik yang dapat menimbulkan depresi napas. ${ }^{19}$

Penelitian di Amerika tahun 2006 mengenai kendala penggunaan regional anestesi dan analgesi, berdasar atas pernyataan dari 38\% dokter bahwa permasalahan yang ditemukan adalah waktu yang dibutuhkan lebih banyak dibanding dengan tanpa tindakan regional, sedangkan 20\% dokter menyatakan bahwa hambatan dalam mempergunakan anestesi regional adalah pengetahuan para perawat melakukan perawatan pasien tersebut tidak ada atau tidak memadai. Suatu penelitian pada perawatan pascabedah mengungkapkan tingkat pendidikan perawat yang rendah mengenai anestesi epidural dan disarankan pelatihan multidisipliner mengenai epidural untuk perawat. Penelitian ini menyatakan bahwa pendidikan atau pelatihan mengenai analgesi epidural pascabedah harus diberikan pada perawat. Penelitian lain mendeskripsikan bahwa penilaian dan tata laksana perawat mengenai teknik analgesi multimodal saat ini belum memadai. ${ }^{19}$

Hal ini sesuai dengan permasalahan yang terjadi di Indonesia khususnya wilayah PERDATIN Jawa Barat karena dari hasil penelitian didapatkan data permasalahan pada blokade epidural yang paling besar adalah dokter anestesi yang berasumsi bahwa kemampuan perawat di ruangan kurang dalam menangani pasien yang mendapatkan epidural sebanyak 38\%. Perawat di ruangan berperan memberikan rejimen obat analgesia epidural sesuai dengan instruksi dokter anestesi. Pengetahuan dan kemampuan perawat yang kurang di ruangan akan membahayakan pasien yang mendapatkan analgesi epidural pascaoperasi. Masalah selanjutnya adalah keterbatasan alat untuk blokade epidural, yaitu $37 \%$ diikuti dengan masalah implementasi teknik melakukan blokade epidural (27\%).

Meskipun penggunaan anestesi regional saat ini dianggap sebagai tindakan yang rutin dilakukan oleh dokter anestesi, namun belum tentu sesuai dengan kondisi di lapangan. Kenyamanan dalam melakukan anestesi regional tidak selalu dimiliki meskipun oleh dokter yang memiliki kompetensi. Penelitian di Amerika menunjukkan bahwa tindakan anestesi spinal dibutuhkan minimal 45 kali tindakan untuk mendapatkan angka keberhasilan 90\%, sedangkan untuk epidural minimal 60 kali. ${ }^{14}$ Hal ini serupa dengan beberapa negara lain, di antaranya di Etiopia didapatkan permasalahan 97\% karena kurang peralatan, $69 \%$ kurang obat-obatan, dan $67 \%$ kurang kemampuan. ${ }^{10}$ Kendala penggunaan teknik regional anestesi dari survei di Arab Saudi, yaitu 2,8\% memakan banyak waktu, $1,4 \%$ penolakan dari operator, dan 0,9\% gagal blokade. ${ }^{9}$ Kendala pada penggunaan anestesi regional di Inggris adalah banyak menghabiskan waktu untuk melakukan teknik regional sebesar $86 \% .^{5}$

\section{Simpulan}

Dokter spesialis anestesi di Jawa Barat yang masih melakukan blokade epidural pada tahun 2015 sebesar $73 \%$, jenis operasi paling banyak ortopedi dengan frekuensi paling banyak satu kali per bulan.

Dokter spesialis anestesi di wilayah Jawa Barat paling banyak melakukan penusukan dengan pendekatan midline, dan identifikasi rongga epidural paling banyak dengan 
pendekatan lost of resistance. Obat anestesi lokal yang paling banyak digunakan untuk blokade epidural adalah bupivakain. Ajuvan yang paling banyak digunakan adalah fentanil.

Permasalahan yang paling banyak, yaitu staf di ruangan yang membantu menangani pasien, keterbatasan alat, dan masalah implementasi teknik dalam melakukan blokade epidural.

\section{Daftar Pustaka}

1. Argyra E, Moka E, Staikou C, Vadalouca A, Raftopoulos V, Stavropoulou E, dkk. Regional anesthesia practice in Greece: A census report. J Anaesthesiol Clin Pharmacol. 2015;31(1):59-66.

2. Rukewe A, Fatiregun A. The use of regional anesthesia by anesthesiologists in Nigeria. Anesth Analg. 2010;110(1):243-4.

3. Wahlen B, Roewer N, Kranke P. Use of local anaesthetics and adjuncts for spinal and epidural anaesthesia and analgesia at German and Austrian University Hospitals: an online survey to assess current standard practice. BMC Anesthesiol. 2010;10(10):4.

4. Elizabeth M, Kelly L. Epidural analgesia in labour. Contin Educ Anaesth Crit Care Pain. 2004;4(4):114-7.

5. Harbi M, Kaki A, Dawlatly KAE, Daghistani $M$, Tahan MRE. A survey of the practice of regional anesthesia in Saudi Arabia. Saudi J Anaesth. 2013;7:367-70.

6. Kang XH, Bao FP, Xiong XX. Major complications of epidural anesthesia: a prospective study of 5083 cases at a single hospital. Acta Anaesthesiol Scand. 2014;58:858-66.

7. Allegri M, Niebel T, Bugada D, Coluzzi F, Baciarello M, Berti M, dkk. Regional analgesia in Italy; a survey of current practice. Eur J Pain Suppl. 2010;4:219-25.

8. Huang J, Gao H. Regional anesthesia practice in China: a survey. J Clin Anesth. 2016;34:115-23.

9. Bauer M, George JE, Seif J, Farag E. Recent advance in epidural analgesia. Anesth Res Pract. 2012;10:1-14.
10. Halle M, Desalegn N, Akalu L. Practice of regional anesthesia and analgesia in Ethiopian Hospital. Int J Med Med Sci. 2015;7(8):130-8.

11. Weiniger CF, Ivri S, Ioscovich A, Ginosar Y. Obstetric anesthesia units in Israel. a national questionnaire based survey. Int J Obstet Anesth. 2010;19(4):410-6.

12. Stourac P, Blaha J, Klozofa R, Noskova P, Seidlova D, Lucie B, dkk. anesthesia for cesarean delivery in the Czech Republic: a national survey. Anesthesia Analgesia. 2015;120(6):1303-8.

13. Aksoy M, Aksoy AN, Dostbil A, Çelik MG, Ahıskalıoğlu A. Anaesthesia techniques for caesarean operations: retrospective analysis of last decade. Turk J Anaesth Reanim. 2014;42(3):128-32.

14. Kopacz DJ, Neal JM, Pollock JE. The regional anesthesia "learning curve": what is the minimum number of epidural and spinal blocks to reach consistency? Reg Anesth. Pain Med. 1996;21(3):182-90.

15. Woods KL, Aldington D. current epidural practice-result of a survey of military anesthetist. J R Army Med Corps. 2010;156(4):393-7.

16. Wantman A, Hacnox N, Howell PR. Techniques for identifying the epidural space: a survey of practice amongst anaesthetist in the UK. Anaesthesia. 2006;61:370-5.

17. Hoffmann VLH, Vercauteren MP, Vruedge JP, Coppejans GH. Posterior epidural space depth: safety of the lost of resistance and hanging drop technique. Br J Anesth. 1999;83(5):809-9.

18. Guay J. The epidural test dose: a review. Anesth Analg. 2006;102:921-9.

19. Khangure N. Adjuvan agents in neuroaxial blockade. ATOTW. 2011;230:1-0.

20. Boyd AM, Eastwood VC, Kalynychet NM, McDonough JP. Clinical perceived barriers to the use of regional anesthesia and analgesia. Acute Pain. 2006;8(1):23-7. 